\title{
Probability of profitable yield response to nitrification inhibitor used with liquid swine manure on corn
}

\author{
P. M. Kyveryga • T. M. Blackmer
}

Published online: 9 February 2013

(C) The Author(s) 2013. This article is published with open access at Springerlink.com

\begin{abstract}
Nitrification inhibitors (NI) can be used with liquid swine manure (LSM) to decrease potential $\mathrm{NO}_{3}$ losses, but knowledge specifying when and where NI can increase corn (Zea mays L.) yields is limited. Eleven on-farm evaluation trials (OET) were conducted in 2009 and 15 in 2010 to identify site-specific factors for using Instinct (an encapsulated form of nitrapyrin) with LSM in Iowa. Farmers injected LSM in the fall in at least three field-long strips with and without NI. Yield responses (YR) to NI were calculated by dividing yield monitor data into $50-\mathrm{m}$ cells within each field. Hierarchical models were used to estimate predictive probabilities of profitable YR for two categories of monthly average rainfall and soil drainage. On average, NI produced no YR in relatively normal 2009 and a $0.15 \mathrm{Mg} \mathrm{ha}^{-1}$ YR in extremely wet 2010. The NI did not change lateseason corn $\mathrm{N}$ status but half of corn stalk nitrate test (CSNT) samples were $\mathrm{N}$ deficient in 2009 and about $65 \%$ in 2010. Fields receiving $>90 \mathrm{~cm}$ March through August rainfall in 2010 were predicted $65 \%$ more likely to have economic YR $\left(>0.13 \mathrm{Mg} \mathrm{ha}^{-1}\right)$ than fields receiving $<90 \mathrm{~cm}$ rainfall. Within-field variability in YR was about four times greater than among-field variability, but within field-level factors had no significant effects on YR. The NI effects may not have lasted long enough to increase yields across all OET and predictive probabilities suggest that NI may produce profitable YR only when spring and summer rainfall exceed the long-term averages by more than $40 \%$.
\end{abstract}

Keywords Late-season digital aerial imagery - Late-season corn stalk nitrate test . Hierarchical models and Bayesian analysis

P. M. Kyveryga $(\bowtie)$. T. M. Blackmer

On-Farm Network, Iowa Soybean Association, 1255 SW Prairie Trail Parkway, Ankeny, IA 50023, USA

e-mail: pkyveryga@iasoybeans.com

T. M. Blackmer

e-mail: tblackmer@iasoybeans.com 


\section{Introduction}

In Iowa, nitrification inhibitors (NI) have been historically used with anhydrous ammonia to retard conversion of $\mathrm{NH}_{4}$ to $\mathrm{NO}_{3}$. Slowing nitrification of fall-applied anhydrous ammonia can provide farmers with insurance from potential large $\mathrm{N}$ losses due to leaching and denitrification during wet springs.

One of the most commonly used NI during the last 40 years was nitrapyrin (2-chloro-6(trichloromethyl)pyridine) with the commercial name "N-Serve". Numerous experiments were focused on studying the efficacy (often expressed as timing and length of inhibition) of this NI and its effects on corn (Zea mays L.) yield. Some studies reported measurable N fertilizer savings and positive yield responses (YR) to nitrapyrin while others reported no significant benefits in saved $\mathrm{N}$ or additional grain yield (Cerrato and Blackmer 1990; Hoeft 1984; Parkin and Hatfield 2010; Quesada et al. 2000; Randall and Vetsch 2005; Wolt 2004).

Numerous factors influence the likelihood of a corn YR to this NI. Therefore, economic performance (i.e. potential $\mathrm{N}$ fertilizer saving and additional yields) of nitrapyrin in corn production can be extremely variable (Blackmer 1986). For example, a study in Iowa in a relatively wet year showed a twofold decrease in the percentage of nitrification of fallapplied anhydrous ammonia from nitrapyrin when soils had a $\mathrm{pH}<6$ than in soils with $\mathrm{pH}>7$ and presence of free carbonates (Kyveryga et al. 2004). However in the same study, the effect of NI on nitrification was much smaller than the effect of soil $\mathrm{pH}$. In addition, positive YRs to nitrapyrin were observed mostly in high $\mathrm{pH}$, calcareous soils (Ellsworth 2001), where nitrification rates of anhydrous ammonia were much higher (Kyveryga et al. 2004).

Approximately $25 \%$ of the fields planted to corn in Iowa receive annually liquid swine manure (Sus scrofa) (LSM), which contains a considerable amount of $\mathrm{N}$ as $\mathrm{NH}_{4}(>80 \%)$. Liquid swine manure management is more challenging than that of commercial $\mathrm{N}$ fertilizer because manure is usually applied in the fall before soil temperatures are low enough to substantially retard nitrification of $\mathrm{NH}_{4}$. As a result, relatively high nitrification rates in the fall can cause large losses of nitrified $\mathrm{NH}_{4}$ (i.e. $\mathrm{NO}_{3}$ leaching) applied with manure after excessive spring or early summer rainfall events (Balkcom et al. 2003; Hansen et al. 2004). To reduce spring $\mathrm{NO}_{3}$ losses from leaching and denitrification, NI might be used with fallinjected LSM (McCormick et al. 1983; Calderón et al. 2005).

Nitrapyrin efficacy is often reduced because of its potential volatilization losses, fixation by soil organic matter and the relatively short time of its inhibition, measured as several weeks (Gomes and Loynachan 1984; Keeney 1986). Instinct ${ }^{\mathrm{TM}}$ is an encapsulated form of nitrapyrin (Dow AgroSciences LLC, Indianapolis, IN, USA). Compared with nitrapyrin, Instinct is designed to be better protected from volatilization losses and permanent fixation by soil organic matter or clay minerals and to provide the slow release of NI with potentially longer inhibition action.

Little is known about site-specific factors that may affect the efficacy and economic performance of Instinct used with LSM. In the past, collecting site-specific information about YR to NI was relatively expensive. Currently, precision agriculture technologies can help identify potential site-specific factors that influence economic YR to Instinct. Farmers can use yield monitoring technologies and GPS to evaluate performance of many fertilizer products and technologies on their fields across a wide range of management practices, soil types, and weather conditions (Blackmer and Kyveryga 2010; Griffin et al. 2008).

On-farm evaluation trials (OET) are usually conducted without following traditional field experimental designs (e.g. randomized complete block design). Also, a common 
requirement for treatment randomization within controlled small-plot experiments is often waived for OET, primarily to more easily accommodate treatment applications by farmers and treatment verification by researchers. Treatment randomization is important to avoid potential bias that can be caused by previous management history, patterns of farm machinery traffic or non-uniform distribution of crop residues during harvest of the previous crop. The potential bias from non-randomized fertilizer treatments in OET is believed to be less critical when a relatively large number of trials are conducted at different locations with different management practices having different equipment traffic patterns and with treatments that are usually applied at the field scale. The basic idea is to use data collected in OET to modify and refine management for a given farm or field over time. This approach is also called "adaptive $\mathrm{N}$ management". In contrast to controlled small-plot experiments conducted by researchers, farmers are responsible for all operations when conducting their OET. These operations typically include treatment applications, making in-season observations and harvesting the crop. Researchers typically monitor data quality and analyze the data.

Protocols for conducting OET need to be somewhat flexible because of farmer interests, physical characteristics of the landscape and ability to accommodate the desired treatments. Kyveryga and Blackmer (2012) conducted a large-scale on-farm evaluation study to develop procedures for calibrating commonly used $\mathrm{N}$ diagnostic tools for measuring lateseason corn N status. Subsequently, Kyveryga et al. (2013) identified factors that influence the risk associated with reducing normal $\mathrm{N}$ fertilizer application rates by about one-third across Iowa. The objective of this study was to utilize yield monitoring and GPS technologies in OET to identify field and within-field factors for which the use of Instinct (an encapsulated form of nitrapyrin) with LSM might be profitable in spatially variable corn fields in Iowa.

\section{Materials and methods}

This study was based on utilizing OET conducted by farmers using their available yield monitoring and GPS equipment for site-specific assessment of different $\mathrm{N}$ management practices. Instinct nitrification inhibitor was evaluated in 11 OET in 2009 and in 15 trials in 2010 (Fig. 1). Each trial had two alternated treatments of injected LSM with and without Instinct (Fig. 2). Treatments were replicated three to six times and were applied the full length of each field. Liquid swine manure was applied at rates considered optimal for corn. For corn after soybean (C-S), the average $\mathrm{N}$ rate applied with manure was about $190 \mathrm{~kg}$ of total $\mathrm{N} \mathrm{ha}^{-1}$ in 2009 and about $220 \mathrm{~kg}$ of total $\mathrm{N} \mathrm{ha}^{-1}$ in 2010 . Manure application rates were determined based on total (organic plus mineral) $\mathrm{N}$ content in the manure. Three or four manure samples were collected during the manure applications and sent to a laboratory for analysis. In about $60 \%$ of the trials, farmers applied additional commercial $\mathrm{N}$ at a rate of about $45 \mathrm{~kg} \mathrm{~N}$ ha $^{-1}$ to avoid potential large $\mathrm{N}$ shortages from excessive rainfall in April 2009 and June 2010 (Fig. 3). All trials were C-S except for three that were in continuous corn. The manure was injected to a depth of 15-20 cm with disks or coulters to avoid ammonia losses. Instinct was mixed with the manure and applied at a rate of $1 \mathrm{~L} \mathrm{ha}^{-1}$. In both years, manure application dates ranged from early November to early December (data not shown), with the majority of the fields receiving LSM during the last 2 weeks of November. 


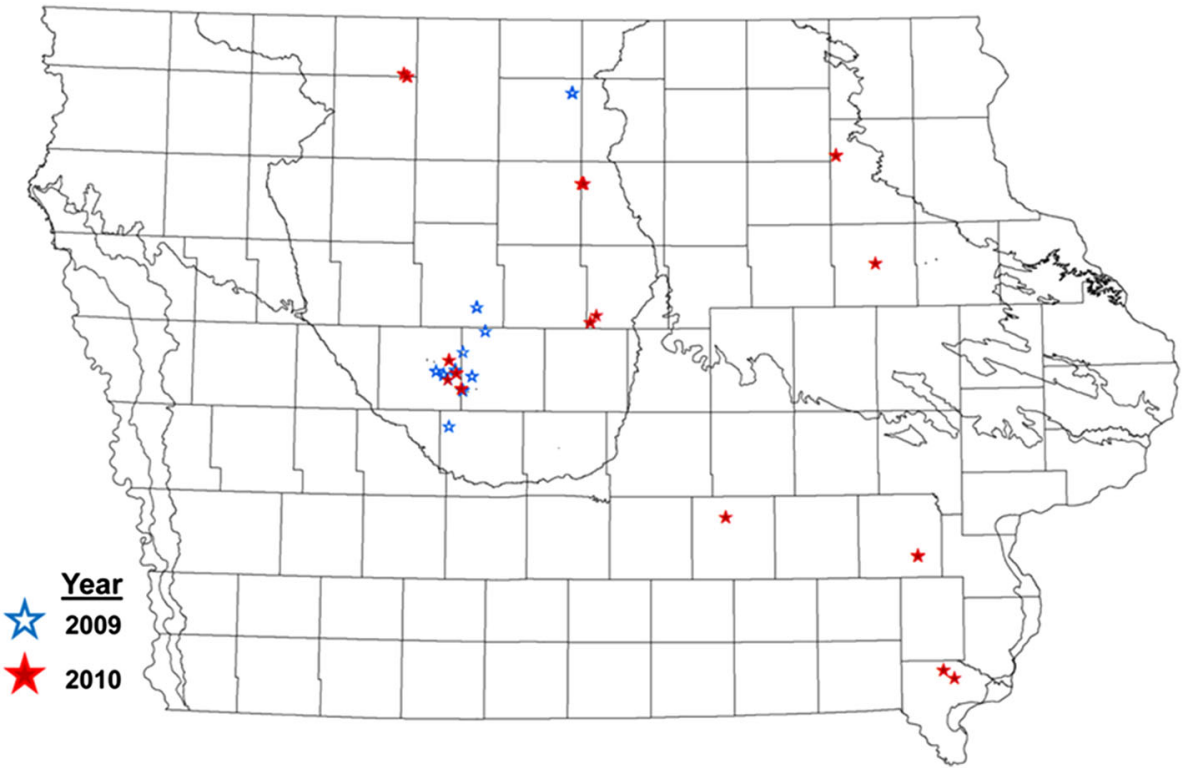

Fig. 1 Locations of on-farm evaluations trials (OET) evaluating site-specific benefits of Instinct nitrification inhibitor used with fall-injected liquid swine manure (LSM) in Iowa

Fig. 2 Treatment layout, locations of yield differences between two treatments and areas for collecting soil and corn stalk nitrate test (CSNT) samples within a field evaluating sitespecific benefits of nitrification inhibitor (NI) applied with fallinjected liquid swine manure (LSM)

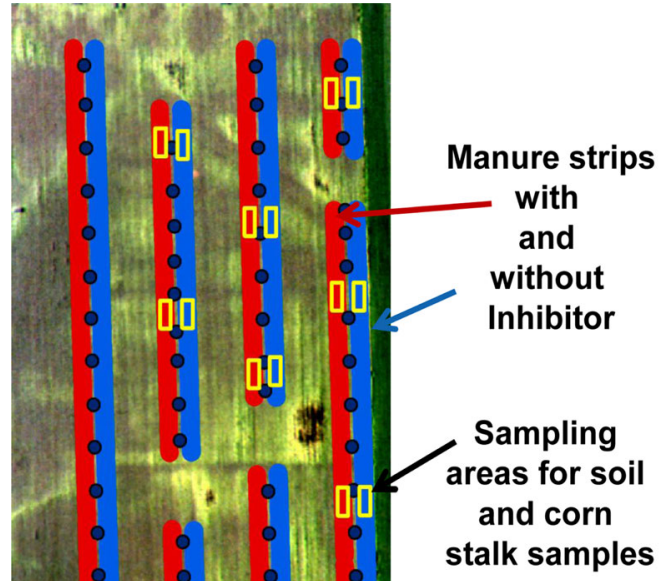

Grid locations of yield differences between two treatments 
Fig. 3 Average monthly rainfall for on-farm trials evaluating Instinct nitrification inhibitor (NI) used with fall-injected liquid swine manure (LSM) in 2009 and 2010

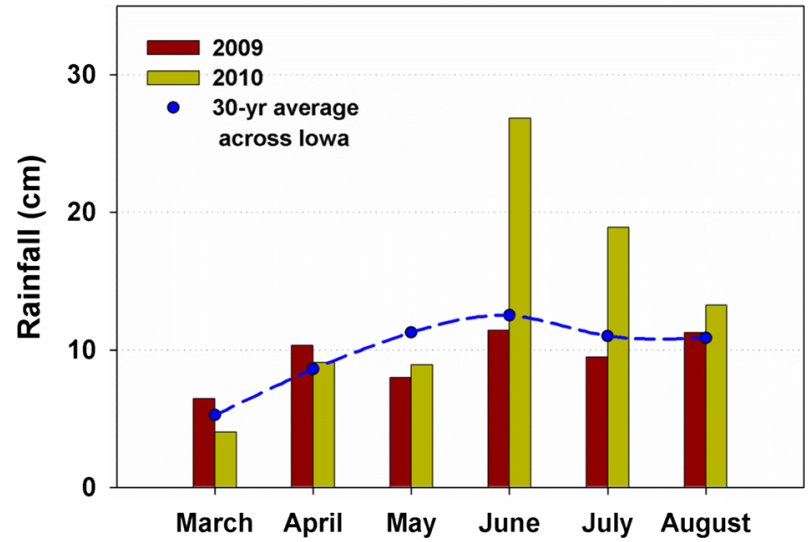

The width of the treatments was determined by the width of manure applicators and the number of applicator passes applied in each strip. The majority of the treatments were from 10 to $30 \mathrm{~m}$ wide.

\section{Evaluating corn $\mathrm{N}$ status}

One of the requirements for conducting OETs is to use various diagnostic tools to evaluate corn $\mathrm{N}$ status. Corn $\mathrm{N}$ status was evaluated using the late-spring soil nitrate test (Binford et al. 1992a), the late-season corn stalk nitrate test (CSNT) (Binford et al. 1992b), and lateseason digital aerial imagery of the corn canopy (Kyveryga et al. 2012). The late-spring soil nitrate test is used to identify whether fields receiving preplant $\mathrm{N}$ applications require additional sidedress $\mathrm{N}$ applications after corn plants reach the V5 or V6 growth stage (Ritchie et al. 1993) to offset potential $\mathrm{N}$ losses from excessive spring rainfalls. In this study, the soil test was also used to determine whether $\mathrm{NI}$ affected concentrations of $\mathrm{NH}_{4}-$ $\mathrm{N}$ and $\mathrm{NO}_{3}-\mathrm{N}$ in the soil in early June. The CSNT provides an end-of-season assessment of corn $\mathrm{N}$ status, which is classified into four sufficiency categories: deficient, marginal, optimal and excessive. Fields testing deficient in corn $\mathrm{N}$ status usually have a relatively high probability of economic YR to additional $\mathrm{N}$ while fields testing excessive have a relatively low probability of economic YR to additional N. The last diagnostic tool, lateseason digital aerial imagery of the corn canopy was used to identify areas within fields that were likely deficient in N and detect potential errors in fertilizer and LSM applications where a differential YR might be expected.

Sampling areas for CSNT in each trial were selected using the visible color (red, green and blue) bands in digital aerial imagery of the corn canopy. The sampling areas were selected to capture a wide range of variability in the canopy reflectance to better relate canopy characteristics to potential yield differences between the two treatments. The imagery was collected by a commercial aircraft in mid or late August. Each aircraft had four 12-bit digital cameras (blue, green, red and near-infrared) with a charge coupled display array of $1600 \times 1200$. The imagery was taken from a height of about $2400 \mathrm{~m}$ above the ground producing imagery with about $1 \mathrm{~m}$ spatial resolution. Twenty to 30 individual images were taken from each field and the individual images were orthomosaiced into one composite image for the entire field. Composite images were GIS readied and georeferenced. For more information about the imagery processing, normalization, and enhancement see Kyveryga et al. (2012). 
Soil and corn stalk samples were collected at nine sampling areas for each treatment in each trial (Fig. 2). Soil samples were collected only in 2010. The sampling depth was $30 \mathrm{~cm}$. Soil samples were collected when corn plants were at the V5-6 growth stage. A composite soil sample in each sampling area within a trial consisted of three sets of eight individual soil cores taken in different relative locations between three pairs of corn rows. Corn stalk samples were collected about 3 weeks after corn grain reached the black-layer stage (physiological maturity) or just before harvest. In each sampling area, 10 individual corn stalks were collected from a $10 \mathrm{~m}$ length of two-adjacent rows, avoiding plants that were irregularly spaced, damaged or barren. Both soil and stalk samples were analyzed for $\mathrm{NO}_{3}$.

Image analysis

Digital aerial imagery was used to identify differences in reflectance of the corn canopy between the two treatments with and without NI. The reflectance values for each band were extracted from an area of about half the width of the manure treatments. The area for extracting the reflectance was identified by drawing a line in the middle of a treatment area and creating a buffer about half of the treatment width. Reflectance values for all replications in each trial were extracted using the Zonal Statistics Tool of Spatial Analysis in ArcGIS Desktop 9.3.1 software (Environmental Systems Research Institute, Redlands, CA, USA). Only green reflectance values were used in the analysis because green-band reflectance is the most sensitive to changes in corn chlorophyll concentration at the end of corn growing season (Hatfield et al. 2008).

Data processing and statistical analysis

Farmers harvested individual manure treatments with grain combines equipped with GPS and yield monitors that recorded yield observations every $1 \mathrm{~s}$. Yield data were cleaned by deleting observations that were located $<50 \mathrm{~m}$ from the beginning and end of each manure strip, and from around flooded areas, waterways and buffer strips. Individual yield observations were aggregated into $50 \mathrm{~m}$ long grid cells along each pair of treatments. Yield responses (YR) were calculated as differences in aggregated yields between the treatments with and without NI. Each trial had from 50 to 300 individual YR values (Fig. 2). Yield response observations that were two standard deviations (SD) above or below the mean YR for a trial were also eliminated.

Monthly rainfall estimates for each trial were obtained from the Iowa Environmental Mesonet (2012). Soil characteristics such as soil organic matter (SOM), slope and soil drainage class were derived from digital soil maps available from the Iowa Cooperating Soil Survey (2003).

Hierarchical models with Bayesian statistics were used to evaluate the effects of field-level factors such as average monthly and cumulative seasonal rainfall and within-field level factors such as SOM, slope or soil drainage class on YR relative to the NI treatment. Hierarchical analysis is used to model multiple sources of variability observed at different levels or scales (Gelman et al. 2004; Gelman and Hill 2007; Cressie et al. 2009). The basic premise of hierarchical modeling is to represent complex ecological processes using a series of conditional probability distributions. For two jointly distributed random variables, a conditional distribution specifies probabilities of observing one variable given the value of the other.

In our study, the general hierarchical model comprised three levels: data, field, and regional (Kyveryga et al. 2013). The data model included a distribution of YR values 
$\left(\mathrm{YR}_{n j}\right.$ ) within a trial (where $n=1, \ldots, N$ ), for an individual grid cell (where $j=1, \ldots, M$ ) to be normally distributed with a mean $\mu_{n}$ and a precision $\lambda_{n}$ unique for that trial. The precision parameter was defined as the reciprocal of variance: the higher the precision, the lower the variation. The data model level was expressed as a conditional distribution of $\mathrm{YR}_{n j}$, given $\mu_{n}$ and $\lambda_{n}$,

$$
\left[\mathrm{YR}_{n j} \mid \mu_{n}, \lambda_{n}\right] \sim N\left(\mu_{n}, \lambda_{n^{-1}}\right)
$$

The field-level model was expressed as a conditional distribution of trial means $\mu_{n}$, given regional mean $\mu_{0}$ and regional precision $\lambda_{0}$.

$$
\left[\mu_{n} \mid \mu_{0}, \lambda_{0}\right] \sim N\left(\mu_{0}, \lambda_{0^{-1}}\right)
$$

In the regional process model, the trial precision parameters $\lambda_{n}$ were assumed to follow a gamma distribution with parameters $\alpha$ and $\beta$. A conditional distribution of $\lambda_{n}$, given $\alpha$ and $\beta$, was expressed as

$$
\left[\lambda_{n} \mid \alpha, \beta\right] \sim \operatorname{gamma}(\alpha, \beta)
$$

The parameters $\mu_{n}$ and $\lambda_{n}$ control YR distributions for individual trials. The regional parameters $\mu_{0}$ and $\lambda_{0}$ control the probabilities with which various mean differences in YR are observed among the trials. The parameter $\mu_{O}$ represented the average YR across trials. For simplicity, we expressed precision parameters values as standard deviations (SD). A ratio of $\alpha / \beta$ of gamma distributions was used to calculate the average within-field SD.

Bayesian analysis was used to quantify the uncertainty in parameters for the field and regional-level models. In Bayesian statistics, parameters are assigned to prior distributions to represent knowledge about possible values of those parameters before observing data. The observed data or sample distributions are then used to update this knowledge and make inferences about the parameter values on the basis of posterior distributions. Simply, posterior distributions show probabilities of observing specific parameter values (e.g. mean and variance) conditioned on the observed data.

For prior distributions, normal priors were used for the regional mean $\mu_{0}$, and gamma priors were used for $\lambda_{0}, \alpha$, and $\beta$. Posterior distributions were obtained using Markov Chain Monte Carlo simulation (Gelman et al. 2004), with a Gibbs sampling algorithm, which drew 10000 random samples from each posterior after a suitable burn-in period of about 100 iterations. The Gibbs sampling algorithm produced probability values simulated from joint posterior distributions.

From posterior simulations, we obtained posterior distributions for regional mean YR, $\mu_{0}$, regional precision, $\lambda_{0}$, and regional within-field precision, $\alpha / \beta$. The uncertainty in parameters of posterior distributions was quantified using $90 \%$ credible intervals, with the lower bound chosen as the $5 \%$ quantile of the posterior and the upper bound as the $95 \%$ quantile.

Posterior predictive distributions were used to generate distributions of field-level means, $\mu_{n}$, for fields not actually studied or observed but assumed to follow the same model as the observed data. To use posterior predictive distributions to estimate potential regional (state-wide) YR to NI (which is a proxy for recommendations for other areas), we assumed that our number and spatial distribution of OET across the state were adequate to represent the most common management practices or site-specific conditions observed across Iowa (Fig. 1). Posterior predictive distributions were plotted as cumulative probability densities to estimate the probability of economic YR $\left(>0.13 \mathrm{Mg} \mathrm{ha}^{-1}\right)$ from NI using average corn and NI prices observed during the 2 years of this study. All calculations were 
done using the statistical software $\mathrm{R}$ ( $\mathrm{R}$ Development Core Team 2009). More details for using Hierarchical models and Bayesian statistics to analyze data collected from OETs can be found in Kyveryga et al. (2013).

\section{Results and discussion}

Yield response to inhibitor in each year

Parameters of simulated posterior distributions of corn YR to NI are shown in Table 1. The regional mean, regional (across fields), and within-field average SD are shown for both years of the study and for two categories of trials based on soil drainage class and cumulative growing season rainfall observed in 2010. Across all trials, NI did not increase corn yield in 2009 but it increased corn yield by $0.15 \mathrm{Mg} \mathrm{ha}^{-1}$ in 2010 . The posterior $90 \%$ credible intervals for the field-level mean YR ranged from 0.03 to $0.30 \mathrm{Mg} \mathrm{ha}^{-1}$, indicating a significant positive YR to NI. Thus, NI might have decreased $\mathrm{N}$ losses from the manure in 2010, a year with above-normal rainfall during the summer (Fig. 3). Meanwhile, a difference in YR between 2009 and 2010 was relatively marginal because both credible intervals for posterior regional mean YR slightly overlapped (Table 1). The lack of positive YR to NI in 2009 could be partially explained by slightly below normal rainfall during June, July and August and therefore, the absence of considerable $\mathrm{N}$ losses from fallapplied LSM.

Based on regional and within-field average SD, within-field variability in YR in both years was three to four times larger than across field variability (Table 1). Slightly larger within-field variability was observed in 2009 than in 2010. Also, it is noteworthy that in a relatively responsive year like 2010 , within-field variability was about three times larger than the posterior regional mean YR, indicating relatively large uncertainty when

Table 1 Posterior regional means, average regional (across fields) and within-field standard deviations (SD) for corn yield response (YR) to Instinct nitrification inhibitor evaluated with fall-injected liquid swine manure (LSM) in 11 on-farm trials in 2009 and 15 trials in 2010

\begin{tabular}{llll}
\hline Variable & Posterior regional mean $\left(\mathrm{Mg} \mathrm{ha}^{-1}\right)$ & \multicolumn{2}{l}{ Posterior average SD } \\
\cline { 3 - 4 } & & Regional $\left(\mathrm{Mg} \mathrm{ha}^{-1}\right)$ & Within field $\left(\mathrm{Mg} \mathrm{ha}^{-1}\right)$ \\
\hline Year & & 0.15 & 0.62 \\
2009 & $0.0(-0.11,0.10)$ & 0.20 & 0.52 \\
2010 & $0.15^{\mathrm{a}}(0.03,0.30)$ & & \\
2010 & & & 0.14 \\
Soil drainage & & 0.30 & 0.51 \\
$\quad$ Well & $0.09(-0.03,0.22)$ & & \\
Poor & $0.18(0.02,0.37)$ & & 0.47 \\
2010 & & 0.13 & 0.22 \\
Growing season rainfall & 0.22 & \\
$<90 \mathrm{~cm}$ & $0.0(-0.15,0.14)$ & &
\end{tabular}

In parentheses are $90 \%$ credible intervals

${ }^{\text {a }}$ A yield response $>0.13 \mathrm{Mg} \mathrm{ha}^{-1}$ was considered profitable from applications of NI 
estimating average YR. Although the large within-field variability could be attributed to many factors (e.g. possible errors generated by yield monitors or large soil spatial variability), the data in Table 1 confirm results of many previous controlled studies also showing large variability and uncertainty when measuring YR to NI in field conditions (Blackmer 1986; Ellsworth 2001).

Posterior predictive distributions were simulated to predict probabilities of field-average YR in unobserved situations that follow the same model. These probabilities can be used to make state-wide recommendations for using NI with LSM across many fields with similar soil and weather conditions. The posterior predictive cumulative probability distributions in Fig. 4 indicate the probability at which the predicted YR is equal to or less than a specified value. Using a break-even YR $\left(0.13 \mathrm{Mg} \mathrm{ha}^{-1}\right)$ as a reference in Fig. 4 , the cumulative distribution curves allowed estimating the probability of profitable YR to NI. These probability values can be estimated by subtracting the probability identified at the intersection of the cumulative distribution curve and the break-even YR from 1. For example, about $20 \%$ of the trials were predicted with a profitable field-level YR in conditions similar to 2009 and about $50 \%$ of trials with a profitable YR in conditions similar to 2010. The probability of profitable YR can change if the break-even line is shifted left or right in Fig. 4 due to large changes in the price of corn or NI. Although obtaining a profitable YR to inhibitor was about twice as likely in 2010 than 2009, it is important to stress that a $50 \%$ probability of receiving a profitable YR in 2010 could partially be due to random chance. Thus, one of the objectives of this study was to identify field or within-field level factors that can explain some of the observed variability in YR and increase or decrease the likelihood of profitable YR in each year.

Factors affecting yield response to inhibitor at field and within-field levels

Because of large within-field variability (Table 1), we tested whether within-field factors such as SOM or soil drainage class derived from digital soil maps had influenced YR. The analysis showed that none of the factors used were significant in 2009. But in 2010, poorly drained soil map units within the fields had a posterior regional mean YR of $0.18 \mathrm{Mg} \mathrm{ha}^{-1}$, which was about twice that of well-drained soil map units (Table 1). This difference in YR suggests that NI may have prevented $\mathrm{N}$ losses within poorly drained areas of the fields

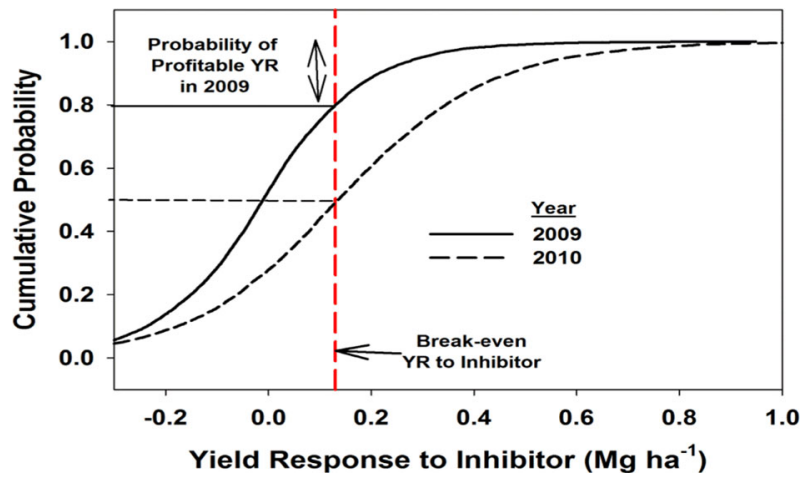

Fig. 4 Posterior predictive distributions of field-average yield response (YR) to nitrification inhibitor (NI) in on-farm trials evaluating site-specific benefits of NI used with fall-injected liquid swine manure (LSM) in 2009 and 2010 (Color figure online) 
studied in 2010. However, $90 \%$ credible intervals for the posterior means of the two soil drainage categories largely overlapped, suggesting that the estimated difference between the two drainage classes is largely uncertain. In addition, posterior predictions for unobserved fields showed the probability of profitable YR within poorly drained soils was only about $15 \%$ greater than within well drained soils (Fig. 5a).

In 2010, fields with excessive cumulative growing season rainfall $(>90 \mathrm{~cm}$ from March through August) were predicted to have a field-level profitable YR about $65 \%$ more often than those with less than excessive rainfall (Table 1 and Fig. 5b). The difference in regional mean YR between the two rainfall categories was above $0.5 \mathrm{Mg} \mathrm{ha}^{-1}$ (Table 1). Classifying the 2010 trials based on cumulative spring rainfall (below normal, $<25 \mathrm{~cm}$ and above normal, $>25 \mathrm{~cm}$ from March through May) also showed that fields with abovenormal rainfall were about $65 \%$ more likely to have profitable YR than those with below normal spring rainfall. Both classifications indicate that a combination of excessive spring and summer rainfalls may have created ideal conditions for $\mathrm{N}$ losses, and therefore, a relatively high chance of NI to produce a profitable corn YR.

Average monthly rainfall observations for the last 20 years for the four OETs located in the southeastern corner of the state indicate that the frequency of above-normal spring and

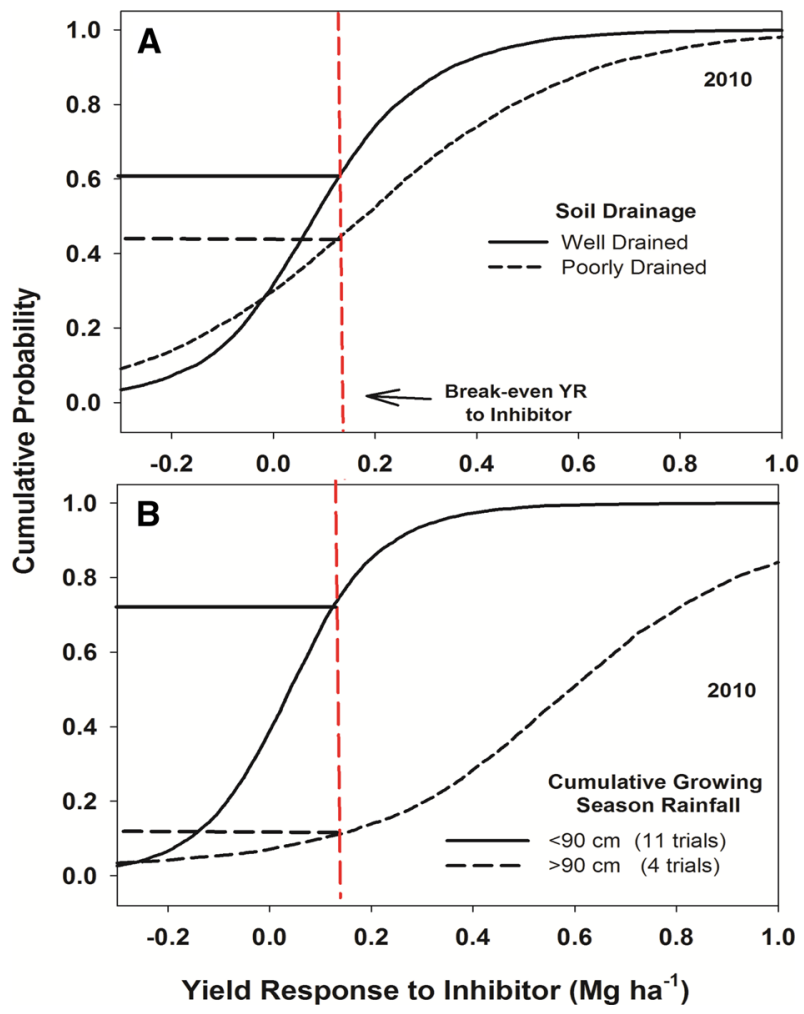

Fig. 5 Posterior predictive distributions of field-average yield response (YR) to nitrification inhibitor (NI) as affected by soil drainage class within fields and cumulative growing season (March through August) rainfall. The probability of profitable YR to NI can be estimated as the distance from 1 on the $Y$ axis to the intersection of the cumulative probability curve with the break-even YR line shown in red. A yield response $>0.13 \mathrm{Mg} \mathrm{ha}^{-1}$ was considered as profitable (Color figure online) 
summer rainfall ( $>65 \mathrm{~cm}$ of total) was about 1 in 2 years and the frequency of excessive spring and summer rainfall $(>90 \mathrm{~cm}$ of the total) was about 1 in 5 years. Therefore, the likelihood of economic YR to NI could be relatively small in this part of the state. However, more studies might be needed because the posterior predictive probabilities for a category of OET with $>90 \mathrm{~cm}$ rainfall in 2010 (Fig. 5b) were estimated using observations from only four locations (Fig. 1).

Soil and tissue testing, and corn canopy reflectance properties

Corn stalk nitrate test (CSNT) sufficiency categories for the two treatments indicated that NI did not affect the late-season corn N status (Fig. 6). But for both treatments, more than half of corn stalk samples were tested as N deficient in 2009 and about $65 \%$ in 2010, suggesting favorable conditions for detecting a positive or profitable YR to additional commercial $\mathrm{N}$ in both years. In fact, in other OETs with similar manure $\mathrm{N}$ rates, an additional $56 \mathrm{~kg} \mathrm{ha}^{-1}$ of commercial $\mathrm{N}$ increased corn yield on average by about $0.5 \mathrm{Mg} \mathrm{ha}^{-1}$ in 2009 and about $0.7 \mathrm{Mg} \mathrm{ha}^{-1}$ in 2010 (data not shown). In addition, a 5-year on-farm study showed that fields receiving fall-application of LSM at the same rates as in this study had a higher probability of profitable YR to additional $\mathrm{N}$ applications when compared with fields that received commercial forms of $\mathrm{N}$ such as anhydrous ammonia applied in the spring or fall, or urea ammonium nitrate solution applied in the spring or at sidedress (Kyveryga et al. 2012). These larger YRs could be attributed to potentially higher $\mathrm{N}$ losses or higher immobilization potential of organic $\mathrm{N}$ applied with LSM (Balkcom et al. 2009).

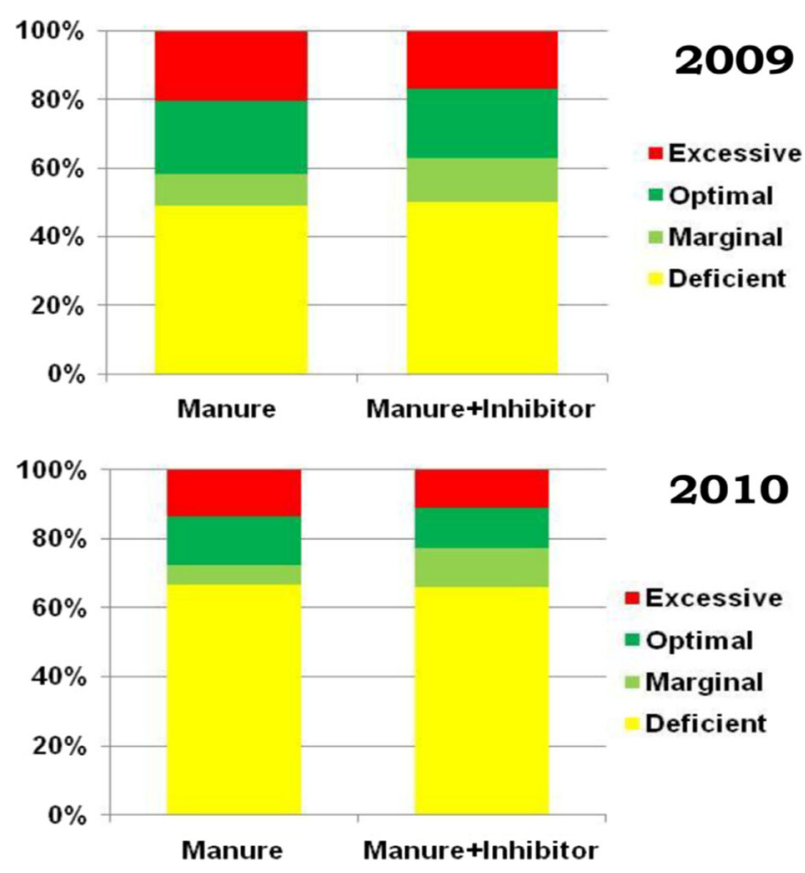

Fig. 6 Percentage of stalk samples tested in different categories of the corn stalk nitrate test (CSNT). In both years, geometric means of stalk $\mathrm{NO}_{3}-\mathrm{N}$ values for the two treatments were the same 
Table 2 Effect of nitrification inhibitor (NI) applied with fall-injected liquid swine manure (LSM) on concentrations of soil mineral-N measured within $30 \mathrm{~cm}$ soil depth in early June of 2010 and on green reflectance of the corn canopy measured in late August in 2009 and 2010

\begin{tabular}{lll}
\hline Year/variable & $\begin{array}{l}\text { LSM } \\
\text { Soil mineral } \mathrm{N}\left(\mathrm{mg} \mathrm{kg}^{-1}\right)\end{array}$ & LSM + inhibitor \\
\hline 2010 & & 6 \\
$\mathrm{NH}_{4}-\mathrm{N}$ & 5 & 23 \\
$\mathrm{NO}_{3}-\mathrm{N}$ & 23 & \\
Green band canopy reflectance (digital units) & & $108(20)$ \\
2009 & $108(20)$ & $73^{\mathrm{a}}(21)$ \\
2010 & $77^{\mathrm{a}}(21)$ & \\
\hline
\end{tabular}

In parentheses are standard deviations (SD)

a Statistically different $(p<.05)$ based on 14-paired comparisons of trial-level mean reflectance values

In 2010, soil mineral- $\mathrm{N}\left(\mathrm{NH}_{4}\right.$ plus $\left.\mathrm{NO}_{3}\right)$ measured within the surface 30 -cm in early June was not affected by adding NI to LSM (Table 2). The effects of NI on nitrification should have been reflected in higher concentrations of soil $\mathrm{NH}_{4}-\mathrm{N}$ in the manure strips with $\mathrm{NI}$, but $\mathrm{NH}_{4}-\mathrm{N}$ concentrations in both treatments were identical. We speculate that, in a majority of the trials, the inhibitor effects may have passed by the time of soil sampling in early June.

On average, NI significantly decreased the green reflectance of the corn canopy by about $4 \%$ compared with the strips without NI, partially confirming the observed positive YR in 2010 (Table 2). However, this difference was too small to classify the 2010 trials into two categories like was done for the spring and summer rainfall (Fig. 5b). The inhibitor also had no effect on within-strip variability in green reflectance of the corn canopy in both years.

Several factors, including soil moisture, soil temperature, soil organic matter levels and soil nitrification potential can influence the efficacy of NI (Keeney 1986). The interactions of these and other factors along with site-specific $\mathrm{N}$ management practices (e.g. timing and method of LSM incorporation, previous crop, tillage) often create a unique combination of conditions for which the probability of YR to NI can be relatively high. Three major conditions are: (1) relatively large $\mathrm{N}$ losses and therefore potential large $\mathrm{N}$ savings from using NI; (2) a low supply of soil-derived $\mathrm{N}$ and (3) lower than optimal $\mathrm{N}$ rates applied with LSM or additional commercial $\mathrm{N}$ fertilizer. If one of these is not met, the likelihood of detecting a positive YR to NI is substantially reduced. Thus, the described methodology utilizing precision farming technologies to collect on-farm observations of corn $\mathrm{N}$ status can be used to identify individual factors and their interactions across and within fields where YR to NI can produce both potential economic and environmental benefits.

\section{Conclusions}

Observations from OETs and analyses using hierarchical modeling showed that the nitrification inhibitor called Instinct (an encapsulated form of nitrapyrin) had no effect on grain yield or late-season corn $\mathrm{N}$ status in 2009, a year with about average rainfall. In 2010, a year with above average rainfall, the inhibitor produced: (1) a positive YR with a $50 \%$ probability of a profitable YR, suggesting that this effect could be due to a random chance; 
(2) slightly decreased the green reflectance of the corn canopy; (3) did not change lateseason corn $\mathrm{N}$ status and (4) did not decrease early season soil $\mathrm{NO}_{3}-\mathrm{N}$ concentrations. In both years, more than half of CSNT samples had deficient N status for both treatments with and without NI.

In 2010, fields with above-normal cumulative spring $(>65 \mathrm{~cm})$ or excessive growing season rainfall $(>90 \mathrm{~cm})$ were predicted to be about $65 \%$ more likely to have profitable YR to NI than those with below-normal spring or excessive growing season rainfall. Despite large spatial variability, we found no significant effects of soil properties on YR to NI. In 2010 only, within field areas having poor soil drainage tended to have a larger YR than well drained areas. Because we found no difference in soil mineral $\mathrm{N}$ measured in early June of 2010, NI effects might be limited during winter or early spring, suggesting a low probability of economic benefits from its use across all fields receiving fall-injected LSM in Iowa.

Site-specific observations collected by farmers in OETs using yield monitoring and GPS technologies can be used by researchers to continually search for factors that influence YR to NI at the field and within-field levels.

Acknowledgments This study was partially funded by Dow AgroSciences, by the Iowa Soybean Association with soybean checkoff dollars and by the Integrated Farm Livestock Management Project from the Iowa Department of Agriculture and Land Stewardship. We are very thankful to all growers, agronomists, and technical providers for participating in the study. Also, this study would not be possible without the OnFarm Network staff that contributed numerous hours for providing logistics support and collecting data.

Open Access This article is distributed under the terms of the Creative Commons Attribution License which permits any use, distribution, and reproduction in any medium, provided the original author(s) and the source are credited.

\section{References}

Balkcom, K. S., Blackmer, A. M., Hansen, D. J., Morris, T. F., \& Mallarino, A. P. (2003). Testing soils and cornstalks to evaluate nitrogen management on the watershed scale. Journal of Environmental Quality, 32, 1015-1024.

Balkcom, K. S., Blackmer, A. M., \& Hansen, D. J. (2009). Measuring soil nitrogen mineralization under field conditions. Communication in Soil Science and Plant Analysis, 40, 1073-1086.

Binford, G. D., Blackmer, A. M., \& Cerrato, M. E. (1992a). Relationships between corn yields and soil nitrate in late spring. Agronomy Journal, 84, 53-59.

Binford, G. D., Blackmer, A. M., \& Meese, B. G. (1992b). Optimal concentrations of nitrate in cornstalks at maturity. Agronomy Journal, 84, 881-887.

Blackmer, A. M. (1986). Potential yield of corn to treatments that conserve fertilizer nitrogen in soils. Agronomy Journal, 78, 571-575.

Blackmer, T. M., \& Kyveryga, P. M. (2010). A systematic approach for using precision agriculture tools for on-farm evaluations in Iowa. CDROM 135. In R. Khosla (Ed.), Proceeding of 10th international conference on precision agriculture, Denver, CO, July 18-21. Madison, WI: ASA, SSSA.

Calderón, F. J., McCarty, G. W., \& Reeves, J. B. I. (2005). Nitrapyrin delays denitrification on manured soils. Soil Science: An Interdisciplinary Approach to Soil Research, 105, 350-356. doi: 10.2134/agronj1983.00021962007500060021x.

Cerrato, M. E., \& Blackmer, A. M. (1990). Effects of nitrapyrin on corn yields and recovery of ammonium$\mathrm{N}$ at 18 site-years in Iowa. Journal of Production Agriculture, 3, 513-521.

Cressie, N., Calder, C. A., Clark, J. S., Ver Hoef, J. M., \& Wikle, C. K. (2009). Accounting for uncertainty in ecological analysis: the strength and limitations of hierarchical modeling. Ecological Applications, $19,553-570$.

Ellsworth, J. W. (2001). Dividing cornfields into soil management units for nitrogen fertilization. PhD Dissertation, Iowa State University, Ames, IA. 
Gelman, A., \& Hill, J. (2007). Data analysis using regression and multilevel/hierarchical models. New York: Cambridge University Press.

Gelman, A., Carlin, J. B., Stern, H. S., \& Rubin, D. B. (2004). Bayesian data analysis. Boca Raton, FL: Chapman and Hall/CRC.

Gomes, S. L., \& Loynachan, T. E. (1984). Nitrification of anhydrous ammonia related to nitrapyrin and time-temperature interactions. Agronomy Journal, 76, 9-12.

Griffin, T., Dobbins, C., Vyn, T., Florax, R., \& Lowenberg-DeBoer, J. (2008). Spatial analysis of yield monitor data: case studies of on-farm trials and farm management decision making. Precision Agriculture, 9, 269-283.

Hansen, D. J., Blackmer, A. M., Mallarino, A. P., \& Wuebker, M. A. (2004). Performance-based evaluations of guidelines for nitrogen fertilizer application after animal manure. Agronomy Journal, 96, 34-41.

Hatfield, J. L., Gitelson, A. A., Schepers, J. S., \& Walthall, C. L. (2008). Application of spectral remote sensing for agronomic decisions. Agronomy Journal, 100, 117-131.

Hoeft, R. G. (1984). Current status of nitrification inhibitor use in U.S. agriculture. In R. D. Hauck (Ed.), Nitrogen in crop production (pp. 561-570). Madison, WI: ASA, CSSA, and SSSA.

Iowa Cooperating Soil Survey (2003). Iowa State University extension and Iowa Department of Land Stewardship, and USDA/NRCS. Retrieved November 12, 2012, from http://icss.agron.iastate.edu/.

Iowa Environmental Mesonet (2012). Iowa State University, Agronomy Department. Retrieved November 12, 2012, from http://mesonet.agron.iastate.edu/rainfall/.

Keeney, D. R. (1986). Inhibition of nitrification in soils. In J. I. Prosser (Ed.), Nitrification (pp. 99-115). Oxford: IRL Press, Special Publication of the Society for General Microbiology.

Kyveryga, P. M., \& Blackmer, T. M. (2012). On-farm evaluations to calibrate tools for estimating lateseason nitrogen status of corn. Agronomy Journal, 104, 1284-1294.

Kyveryga, P. M., Blackmer, A. M., Ellsworth, J. W., \& Isla, R. (2004). Soil pH effects on nitrification of fall-applied anhydrous ammonia. Soil Science Society of America Journal, 68, 545-551.

Kyveryga, P. M., Blackmer, T. M., \& Pearson, R. (2012). Normalization of uncalibrated late-season digital aerial imagery for evaluating corn nitrogen status. Precision Agriculture, 13, 2-16.

Kyveryga, P. M., Caragea, P. C., Kaiser, M. S., \& Blackmer, T. M. (2013). Predicting risk from reducing nitrogen fertilization using hierarchical models and on-farm data. Agronomy Journal, 105, 85-94.

McCormick, R. A., Nelson, D. W., Sutton, A. L., \& Huber, D. M. (1983). Effect of nitrapyrin on nitrogen transformations in soil treated with liquid swine manure. Agronomy Journal, 75, 94-950.

Parkin, T. B., \& Hatfield, J. L. (2010). Influence of nitrapyrin on $\mathrm{N}_{2} \mathrm{O}$ losses from soil receiving fall-applied anhydrous ammonia. Agriculture Ecosystem and Environment, 136, 81-86.

Quesada, J. P., Killorn, R., \& Dierdickx, A. M. (2000). Response of corn grown in two crop rotations to different N rates and nitrapyrin. In Agronomy abstracts (pp. 274). Madison, WI: American Society of Agronomy.

Randall, G. W., \& Vetsch, J. A. (2005). Corn production on a subsurface-drained mollisol as affected by fall versus spring application of nitrogen and nitrapyrin. Agronomy Journal, 97, 472-478.

Ritchie, S. W., Hanway, J. J., \& Benson, G. O. (1993). How a corn plant develops. Special reprint 48 (revised edition). Ames: Iowa State University of Cooperative Extension Service.

R Development Core Team (2009). R: A language and environment for statistical computing. Vienna: R Foundation for Statistical Computing. Retrieved November 12, 2012, from http://www.R-project.org.

Wolt, J. D. (2004). A meta-evaluation of nitrapyrin agronomic and environmental effectiveness with emphasis on corn production in the Midwestern USA. Nutrient Cyclying in Agroecosystems, 69, 23-41. 